\title{
Rudolf Brazda e o Parágrafo 175: a luta de um prisioneiro homossexual nos campos de concentração
}

\author{
Rudolf Brazda and Paragraph 175: the fight of a homosexual prisoner in \\ concentration camps
}

Luana Pagano Peres Molina ${ }^{1}$

Lucas de Melo Andrade ${ }^{2}$

Pedro Arthur Passos da Silva ${ }^{3}$

\begin{abstract}
RESUMO
0 presente artigo busca apresentar as experiências do prisioneiro de guerra Rudolf Brazda, que por ser homossexual foi enviado ao campo de concentração de Buchenwald, na Alemanha Nazista. 0 início do século XX, abarcado pela concepção dos movimentos eugênicos - influenciados pelo darwinismo social - permitiu eventos segregativos e deu amplo poder ao desenvolvimento de políticas preconceituosas, tornando arbitrárias as condenações. Neste contexto, Brazda teve sua liberdade civil violada pelo regime totalitário de Hitler, baseando-se no Parágrafo 175 do Código Penal Alemão, que condenava a homossexualidade masculina no espectro de condenações luxuriosas, passíveis de condenação e recuo de cidadania, obrigando o mesmo a permanecer detido durante 32 meses em um ambiente de exposição dos ideais total itaristas propagados pelo governo alemão. Por fim, ao abordar a biografia de Brazda, pretende-se expor os possíveis avanços na política internacional de defesa dos direitos humanos, com o surgimento da Declaração Universal dos Direitos Humanos, proposta pela ONU, que visa manter a paz e ajustar garantias e deveres essenciais para a preservação dos indivíduos e reconhecimento diplomático de sua dignidade.
\end{abstract}

Palavras-chave: Homossexualidade. Homofobia. Segunda Guerra. Nazismo. Campos de Concentração.

\section{ABSTRACT}

This article present the experiences of Prisoner of War Rudolf Brazda, who was sent to the Buchenwald concentration camp in Nazi Germany as a homosexual. The early twentieth century, embraced by the conception of eugenics movements - influenced by social Darwinism and considered as science allowed for segregation, racist, homophobic events and gave broad power to the development of

1 Doutora em Educação pela UFSCar. Docente Adjunto da Universidade Norte do Paraná. Departamento de História. E-mail: Ippmolina@ hotmail.com

2 Mestre em História. Docente do Instituto Federal do Paraná. E-mail: lucas. andrade@ ifpr.edu.br

3 Graduado em Direito-PUC/PR. E-mail: pedro.arthur@ pucpr.edu.br 
prejudiced policies, making condemnations arbitrary. In this context, Brazda had his civil liberty violated by Hitler's totalitarian regime, relying on Paragraph 175 of the German Criminal Code, which condemned male homosexuality and bestiality in the spectrum of lusty convictions, liable to condemnation and retreat of citizenship, even to remain detained for 32 months in an environment of exposure of the totalitarian ideals propagated by the German government. Finally, addressing the biography of Brazda, it is intended to expose possible advances in international policy for the defense of human rights, with the emergence of the Universal Declaration of Human Rights proposed by the UN, which aims to maintain peace and adjust essential guarantees and duties for the preservation of individuals and diplomatic recognition of their dignity.

Keywords: Homosexuality. Homophobia. Second War. Nazism. Concentration Camp.

\section{A Alemanha Nazista e a Política Eugenista do Entreguerras}

As sociedades modernas europeias do início do século XX, se desenvolveram a partir de experiências totalitárias, ásperos regimes ditatoriais e artífices políticos que comprometiam a isonomia de direitos para determinada parcela da população. Neste contexto, encontra-se o movimento nazista, originado na Alemanha durante o Terceiro Reich, que perdurou entre os anos de 1933 a 1945, resultando na Segunda Guerra Mundial e o genocídio de cerca de milhares de judeus. Outras minorias, como os soldados americanos, os considerados comunistas, homossexuais, presos políticos de oposição ao regime e religiosos de matriz abraâmica somam cerca de 1 milhão de mortes e também eram considerados como inimigos no processo de purificação da raça pelo regime hitleriano.

O eugenismo se originou por meio das hipóteses e teses do darwinismo social - fortemente influenciadas pelas concepções evolucionistas de Charles Darwin -, com a participação do cientista anglo-saxão Francis J. Galton, reconhecido por suas contribuições em relação à genética humana. Por meio de suas análises, chegou-se à conclusão de que a natureza era responsável por determinar as características e comportamentos do indivíduo, e para propiciar a superiorização da raça humana, deveriam celebrar matrimônios seletivos, sempre entre indivíduos da mesma classe social, fomentando a suposição de que a política eugenista - considerada positiva até então - resultaria em cidadãos bem-nascidos, ou seja, eugênicos (GUERRA, 2014, p. 4).

Entretanto, utilizando-se das concepções de Galton, produziu-se outra distinção referente aos estudos eugênicos. 0 cientista norte-americano Charles Davenport, produziu a tese de que por meio de proibições maritais, a eutanásia passiva e outros métodos de exclusão e disseminação da intolerância, seria possível eliminar "as futuras gerações geneticamente incapazes - enfermos, 
racialmente indesejados e economicamente empobrecidos" (GUERRA, 2014, p. 4). Partindo desse princípio, o fim eugenista não era produzir uma concepção de bem-estar social, mas sim justificar cientificamente o desejo segregacional exposto na população do país, que, em parte considerável era descente de europeus nórdicos e repudiavam a mistura de raças que poderia ser ocasionada pelos imigrantes que chegavam ao país das mais variadas regiões.

Davenport, determinado a prosseguir com seus estudos, criou o Eugenics Record Office, instituto de identificação responsável por analisar e julgar a coerência da reprodução e do matrimônio, tendo por objetivo a preservação dos traços fenotípicos dos ascendentes da grande maioria da população. Em 1909, inicia-se uma busca pela regulamentação política das propostas do cientista, que rogava para que a legislação permitisse a livre identificação, controle e erradicação das linhagens indesejáveis, de forma geral, alheias às suas hipóteses.

O método eugenista de Davenport adquiriu autonomia e reconhecimento considerável, sendo adotado progressivamente na maioria dos estados norte-americanos via decretos-lei, iniciando-se pelo estado de Indiana, tradicionalmente conservador. Com o passar dos anos, "a eugenia passou a ser vista como ciência prestigiosa e de conceito médico legítimo, disseminada por meio de livros didáticos e instituições de instrução eugenista" (GUERRA, 2014, p. 5). 0 êxito dos estudos de Charles Davenport originou diversas comissões, congressos e pesquisas direcionadas ao tema, a exemplo do Congresso Internacional de Eugênia e o Comitê Internacional de Eugenia, que posteriormente deram origem à Federação Internacional das Organizações Eugenistas, esta última com amplitude diplomática mundial.

A Alemanha era filiada à federação que regulamentava as propostas do eugenismo negativo, e dessa forma, abriu-se precedentes para que políticos ultranacionalistas incorporassem tais conceitos e os utilizassem como método de governo, adotando-os para a estratégia política do Estado. É neste contexto de apropriação de teorias segregacionistas que as estratégias e normas de conduta do austríaco Adolf Hitler conquistaram espaço político na República Alemã.

O posicionamento nazista, defendia "o extermínio dos judeus e outros grupos étnicos", justificando que tal máxima "tratava-se de uma política médica e pseudocientífica" (GUERRA, 2014, p. 4), culminando inicialmente no repúdio e emigração dos cidadãos judeus, comunistas e homossexuais que viviam no país. Um dos oficiais de Hitler, responsável pelas forças armadas decidiu ir além e propor um plano de extermínio em massa dessa população, reforçando que "a emigração como solução possível deveria ser suplantada pelo plano de eliminação dos judeus". A proposta teve autorização do primeiro-ministro e à época führer Adolf Hitler (LONGERICH, 2008, p. 21). 
Os homossexuais passaram a ser perseguidos, em princípio, pela autonomia que exerciam em garantir seus direitos e em preservar a visibilidade do movimento LGBTTTI (Lésbicas. Gays, Bissexuais, Travestis, Transexuais, Transgêneros e Intersexuais). 0 país teve pioneirismo em políticas de inclusão para a população lésbica, gay, bissexual, transexual, travesti e intersexual. Desde o início dos anos 1910, Berlim já era considerada uma das cidades mais gay-friendly para a comunidade homossexual de toda a Europa, com centenas de bares e livrarias destinados para esse público. A produção de ciência em si já voltava-se para a diversidade sexual. Em 1919, liderado por Magnus Hirschfeld, surge o Instituto de Pesquisas Sexuais, que trouxe incontáveis contribuições acerca da transexualidade - inclusive o cunho do termo -, sendo pioneiro nas pesquisas direcionadas ao tratamento e procedimento cirúrgico de redesignação sexual. 0 médico e cientista também colaborou para a produção cultural de filmes de temática LGBTTI, como Anders als die Andern (Diferente dos Outros), considerado o primeiro filme voltado para a comunidade, gravado na Alemanha em 1920.

Para possibilitar a implementação de políticas públicas voltadas para a população LGBTTI, surgiu em 1922 o Comitê Científico-Humanitário, que possuía o lema da concepção da “justiça por meio da ciência", lutando democraticamente por isonomia de direitos para as minorias. Tal organização e enfrentamento, incomodavam aos anseios dos nazistas, que repudiavam as relações homoafetivas e temiam pelo enfraquecimento no nascimento de bebês. O governo decidiu empenhar-se em buscar maneiras de coibir o exercício da sexualidade e, para tal, utilizou-se do Código Penal Alemão, por meio do artigo 175, que previa: “Luxúria contra o que é natural, realizada entre pessoas do sexo masculino ou entre o homem e 0 animal, é passível de prisão; pode também acarretar a perda de direitos civis" (SCHWAB; BRAZDA, 2012, p. 31).

A preocupação dos líderes do governo acerca da reprodução da população alemã tornou-se explícito durante pronunciamento realizado pelo reichfuhrer da Schutzstaffel, justificando o posicionamento tendo em vista a perspectiva da necessidade da perenidade da raça ariana, repudiando o sexo não reprodutivo, conforme citado:

Em discurso feito em 18 de fevereiro de 1937, o Reichfuhrer SS Himmler declara, ao falar da homossexualidade e o suposto número de homossexuais na população, que "se continuarmos assim, nosso povo corre o risco de ser aniquilado por essa praga". Os homossexuais são considerados indivíduos não reprodutores, e assim, como podem assegurar a perenidade da raça? Por esse discurso, a condenação da homossexualidade não parece mais responder a uma exigência moral, mas sim à necessidade de preservar a raça. Começa então o cadastramento dos homossexuais na Central do Reich para reprimir a homossexualidade e 0 aborto em Berlin (SCHWAB; BRAZDA, 2012, p. 31). 
A tortura era uma eficaz ferramenta utilizada pelas forças nazistas para que essas pessoas, ao serem detidas, acabassem por denunciar de forma induzida outras semelhantes, levando a uma amplitude ainda maior de detenções.

Neste contexto, passou a predominar na nação nazista traços de uma gestão ditatorial, idealizadora da reconstrução da cultura germânica, de um movimento político cujo embasamento encontrava-se no "nacionalismo extremado, autoritarismo, racismo, antissemitismo, belicismo, anticomunismo, antiliberalismo e antiparlamentarismo" (CAETANO, 2010, p. 4).

Em 1945, ocorreu o término da Segunda Guerra Mundial e a rendição da Alemanha com a invasão da União Soviética e Estados Unidos. Foi no pós-guerra que as discussões internacionais tiveram um enfoque a respeito do princípio da dignidade humana e da importância dos seus atributos e concepção como forma de valores mais caros da existência humana, além de entender o princípio da dignidade da pessoa como um dos fundamentos principais do Estado Democrático de Direito e embasou a Declaração Universal dos Direitos Humanos, aprovada em 1948, pela Assembleia Geral das Nações Unidas.

\section{A Biografia como Metodologia}

Este artigo fundamenta-se na biografia e experiência de um dos prisioneiros dos campos de concentração nazista, Rudolf Brazda, que além de permanecer preso durante vários meses, ainda foi testemunha de inúmeras tentativas de reversão da polaridade sexual, que tinha como objetivo a cura/reversão da homossexualidade. Brazda foi um dentre milhares de homossexuais que vivenciaram a intolerância envolta em um regime governamental austero e pode servir de inspiração para gerações futuras, conforme retratado em sua biografia escrita pelo jornalista J ean-Luc Schwab, ao final de 2011.

A respeito do uso da biografia produzida por Jean-Luc Schwab como referencial teórico, entende-se possível seu uso, uma vez que este artigo corrobora a ideia do historiador Avelar (2010), que atribui às novas abordagens metodológicas da História a interpretação de que, selecionando acontecimentos significativos em determinada trajetória de vida, o historiador - herdeiro do papel social da construção de biografias - analisa fatos e situações coerentes, de forma a garantir ao leitor a transmissão das informações de forma realística, e desse modo, embora a biografia não seja considerada um mecanismo preciso, é certo que obras de tal gênero contribuem para o contexto cultural, social e histórico de determinada comunidade ou população, agregando importante fonte 
histórica na medida em que ela retrata o contexto histórico da personagem quando expõe como se deu a infância, o crescimento e os fatos que levaram o indivíduo a praticar suas ações.

Cabe salientar que o processo de implementação da utilização de biografia como referencial de caráter histórico não foi um procedimento simples, tendo seus primórdios apenas após os anos 1960, de forma que pretendia "recuperar a feição humana dos processos históricos" (AVELAR, 2010, p. 158) e, nesse sentido, valorizar o testemunho dos indivíduos nas construções científicas das trajetórias socioculturais. Além disso, Avelar (2010) também nos mostra que a biografia se incumbiu de esclarecer fatos e eventos determinantes da história, considerando o inserido em estruturas, papéis e funções sociais (LE GOFF apud AVELAR, 2010, p. 161). Partindo de tal premissa, o movimento biográfico tornou-se legítimo objeto de estudo para os historiadores e cientistas sociais de forma geral, atestando que o testemunho originado nas construções biográficas foi determinante para fomentar a humanização da história, reforçando a presença testemunhal do indivíduo nos estudos históricos, até então retratados pela perspectiva econômica e organizacional.

Outro importante pesquisador acerca da utilização metodológica das biografias, Pierre Bourdieu (1996), em seu texto A ilusão biográfica, nos possibilita compreender que a trajetória de determinado indivíduo só é proveitosa para o âmbito científico no que concerne aos espaços e esferas sociais nos quais este está inserido na historicidade. Dessa forma, é ilusório relacionar a biografia a uma trajetória linear, unidirecional e relacionada/induzida a todos, conforme o senso comum (BOURDIEU, 1996, p. 183).

Por fim, é possível analisar que a justificativa e importância centrais para a utilização das biografias enquanto metodologia da História se dá pela constante necessidade de humanização dos eventos relatados pelos historiadores, acrescidos de testemunhos que valorizam a feição humana nos processos históricos, na mesma medida em que a importância de tais testemunhos se origina do destaque direcionado aos espaços e esferas sociais aos quais este indivíduo se relaciona. Dessa forma, Rudolf Brazda adquire grande notoriedade a partir da esfera social, da sua vivência e trajetória, conforme relatado durante os eventos que se iniciaram com a ascensão do nazismo alemão.

\section{Rudolf Brazda e o Parágrafo 145}

Por meio do recurso biográfico, juntamente com a sensibilidade crítica do jornalista francês J ean-Luc Schwab, aborda-se a trajetória do último detentor do triângulo rosa vivo. O u seja, o último prisioneiro que portou o uniforme distribuído aos homossexuais nos campos de concentração, que trazia a estampa de um triângulo rosa, invertido e em pano. 
Os dois se conheceram em 2008, quando Schwab soube por meio de um artigo no jornal L'Alsace da existência de um refugiado dos campos de concentração vivendo em Bantzenheim, pequeno distrito próximo a Mulhouse, no leste francês.

Rudolf Brazda nasceu em 26 de junho de 1913, no pequeno vilarejo de Brossen, administrativamente ligado a Meuselwitz, no estado alemão da Saxônia (SCHWAB; BRAZDA, 2012, p. 21). Órfão muito jovem, aos 17 anos, passa pela transitória fase das alterações biológicas e fisiológicas advindas da puberdade, tornando-se um jovem rapaz que "mede pouco mais de um metro e sessenta, tem belos cabelos castanho-claros, meticulosamente ondulados, e um rosto rosado, no qual brilham belos olhos azuis; ele pode parecer um pouquinho afeminado" (SCHWAB; BRAZDA, 2012, p. 23). Desde jovem, Rudolf Brazda demarca posicionamento favorável e aceitação em relação à sua orientação sexual, a homossexualidade, admitindo que, embora tenha afinidade com as mulheres, é certo que "sua atração vai em outra direção" (SCHWAB; BRAZDA, 2012, p. 23).

Para melhor compreensão acerca do conceito e da vivência homossexual, entende-se que 0 termo homossexualidade tem sua origem do grego homos - igual, e trata-se da qualidade de um ser vivo atrair-se física, emocional, estética e espiritualmente por indivíduos do mesmo sexo. Nesse sentido, como pontua a historiadora e educadora sexual Luana Molina (2010, p. 11), a homossexualidade atualmente trata-se da possibilidade de "amar alguém do mesmo sexo, entregar-se à dor e à delícia de sentir-se apaixonado como em qualquer relacionamento no qual criamos laços de ternura". Porém, no período vivenciado por Rudolf, da Europa do entreguerras, em meados iniciais dos anos 1930, a homossexualidade masculina na Europa era vista através do prisma da promiscuidade, baseando-se na forte presença de operários que se prostituíam em banheiros públicos em busca de dinheiro, ${ }^{4}$ além da interpretação como desvio sexual, moral e mental.

Muito embora o debate acerca da origem da homossexualidade fomente interpretações patológicas, vale salientar que, de acordo com a psicóloga e educadora sexual Mary Figueiró (2007, p. 29), a homossexualidade "não constitui doença, nem distúrbio e nem perversão". Reforçando esta tese, desde 1973 a Associação Americana de Psiquiatria julga o tratamento médico contra a homossexualidade como "antiético". Além disso, a partir de 1990, a Organização Mundial de Saúde (OMS), através da Classificação Internacional de Doenças (CID), retirou a homossexualidade da subcategoria patológica de desvio sexual, abandonando a antiga expressão homossexualismo e reformulando-a para homossexualidade, termo livre de interpretações equivocadas.

\footnotetext{
4 Esta busca por dinheiro advinda da classe operária alemã se deve ao fato de que recebiam baixíssimos salários, além da grave crise econômica existente na região no final dos anos 1920, sendo utilizada a prostituição em banheiros públicos como vetor de manutenção da subsistência.
} 
Porém, não é esta a realidade de Rudolf Brazda, cuja sociedade da época intenciona a homossexualidade à condição de doença mental. Continuando assim sua trajetória, como forma de representar outros homossexuais deste período, Rudolf segue seu curso e conhece o jovem Werner, que logo se torna seu namorado e iniciam laços de amizade com um pequeno grupo de amigos homossexuais que também se travestem, utilizam nomes femininos e aproveitam a vida nas cidades alemãs maiores, como Leipzig. Quando vão morar na Tchecoslováquia por um tempo, mantêm contato com os amigos por cartas, que posteriormente serão determinantes na produção de provas para incriminá-lo (SCHWAB; BRAZDA, 2012, p. 26).

Em 1936, Werner e Rudolf Brazda já têm ciência das investidas dos policiais nazistas da Gestapo e de investigações contra os homossexuais que estavam cada vez mais rígidas. Os métodos de investigações levavam à rápida denúncia e instauração de novos inquéritos, conforme acusações eram realizadas e provas colhidas. Em abril de 1937, os policiais encontram Rudolf e o conduzem coercitivamente até o distrito policial do foro de Altenburg.

$\mathrm{Na}$ delegacia, os investigadores utilizam de vários artifícios para chegar à confissão da homossexualidade de Rudolf, do suposto envolvimento amoroso dele com Werner e da coleta de provas sobre os amigos do pequeno grupo de homossexuais que o alemão possuía. Com o objetivo de proteger seu amado, Brazda dá informações desencontradas e atesta firmemente que ambos tinham apenas se conhecido "vagamente". Além disso, Rudolf afirma veementemente não conhecer os demais amigos investigados, justificando que cartas recebidas por ele advinham de uma mulher que morava em Wilhelmshaven, buscando assim o viés explicativo de que era heterossexual (SCHWAB; BRAZDA, 2012, p. 41).

Entretanto, nenhuma dessas afirmações bastaram, e Brazda foi sentenciado em primeira instância por luxúria em 14 de maio de 1937, baseando-se nos parâmetros regimentais do parágrafo/artigo 175 do Código Penal Alemão:

\begin{abstract}
Você foi considerado culpado de um delito punido pelo parágrafo 175. A luxúria entre homens é todo comportamento que seja contrária à moral e acarrete $a$ ação de um no corpo do outro, no caso, a masturbação mútua. Você não pode se escudar em seu instinto mórbido para justificar suas dificuldades de abandonar as práticas sexuais com homens. Só podemos exigir de você um controle melhor de si mesmo. Você, um estrangeiro nascido na Alemanha, deveria ter feito tudo para a esse instinto antinatural, uma vez que sabemos qual é o perigo que a luxúria entre homens representa para todo o povo alemão [...] (SCHWAB; BRAZDA, 2012, p. 46).
\end{abstract}

A sentença do juiz de liberdades se embasa em duas atmosferas:

\footnotetext{
Para o magistrado, a decisão de prendê-lo é duplamente justificada. Suspeitam que ele tenha cometido atos de luxúria com Werner, ainda que ele os negue. $\mathrm{E}$, como os policiais dão a entender, há muitos riscos de que Rudolf se apresse a informar as outras pessoas implicadas daquilo que as espera (SCHWAB; BRAZDA, 2012, p. 42).
} 
Nesse sentido, é importante pontuar algumas relações. Durante a República de Weimar, entre os anos de 1919 e 1932, o parágrafo/artigo 175 do Código Penal Alemão apresentava em sua redação a investida em relação à "luxúria contra o que é natural" ou "widernatürliche unzucht". Dessa forma, o texto original abria precedentes para que os juízes interpretassem sua aplicação às uniões que envolvessem relações sexuais diretas entre homens homossexuais ou entre homem e animais, classificadas como bestialidades. A partir de 1933, com os nazistas no poder, o Código Penal Alemão foi reformado e o parágrafo 175 redigido para apenas "unzucht", ou "luxúria", dando posterior margem para que os magistrados interpretassem além das relações de coito e passassem a criminalizar também a masturbação mútua, realizada entre tais grupos específicos, como citados anteriormente.

Dessa forma, Rudolf Brazda, como mostram Schwab e Brazda (2012), foi condenado por "luxúria ao se relacionar com um homem", resultando em sua condenação à prisão por "seis meses e ao pagamento das custas judiciais" (SCHWAB; BRAZDA, 2012, p. 47).

Os meses se passam e em dezembro de 1937 Rudolf é liberto, carregando consigo a titularidade de persona non grata, que o caracterizava como desertor, "um criminoso no país que 0 viu nascer" (SCHWAB; BRAZDA, 2012, p. 50), expedida pelo Ministério Público Alemão. Em 8 de agosto de 1942, é preso novamente, só que dessa vez é mandado junto com outros 50 detentos para o campo de concentração de Buchenwald. Lá recebe uniforme, a matrícula 7952 e inicia o trabalho nas pedreiras, onde posteriormente retorna para a sua profissão fora dos campos: ser telhador (SCHWAB; BRAZDA, 2012, p. 119).

Como telhador, Rudolf é transferido de barracão e passa a integrar um ambiente com maioria de detentos portadores de triângulos vermelhos, os deportados políticos. É certo que "sua profissão e suas afinidades comunistas agradam a muitos" (SCHWAB; BRAZDA, 2012, p. 122). Porém, isso não $o$ impede de vivenciar as experiências proporcionadas pelos nazistas aos detentos dos campos de concentração, e em relação a isso:

\begin{abstract}
Acabamos nos habituando à ideia de poder morrer a qualquer instante. Não tínhamos medo de morrer e, se fôssemos pegos, poderia ter sido fatal. Ver gente morrendo nos deixava quase indiferentes, pois isso era constante no cotidiano. Hoje, choro toda vez que me lembro desses instantes terríveis, mas na época eu endureci para sobreviver. Como os outros (SCHWAB; BRAZDA, 2012, p. 126).
\end{abstract}

Além disso, passou por alguns tratamentos experimentais que ocasionaram consequências irreversíveis para boa parte dos prisioneiros homossexuais, causando desde desconfortos consequentes dos desequilíbrios hormonais provocados em sua estrutura fisiológica, até a morte destes. Estima-se que a principal causa de morte de homossexuais nos campos de concentração foi 
o tratamento de cura dos homossexuais proposto por Vaernet, no interior de Buchenwald, que concentrava a maior parcela dos prisioneiros do triângulo rosa. Em relação a isso, as teóricas Santana e Volpato (2014), referenciando Lima (2014), puderam aferir a perplexidade do método:

Ele [Vaernet] castrou seus pacientes no campo de Buchenwald e depois injetou doses muito altas de hormônios masculinos, para observar sinais de "masculinização". Estima-se que $55 \%$ dos gays que entraram nos campos de concentração morreram - algo entre 5 mil e 15 mil pessoas (LIMA apud SANTANA; VOLPATO, 2014, p. 2).

Em 1945, Buchenwald tornou-se o maior campo de concentração nazista, com cerca de 110 mil prisioneiros, incluindo os campos satélites. Com a superlotação, iniciou-se o processo de evacuação dos campos a partir de 7 de abril de 1945; além disso, a invasão americana aos campos era cada vez maior, assim como a presença de conflitos armados entre estes. Em 11 de abril de 1945, os americanos "tomam o controle do prédio da entrada principal [de Buchenwald], que está quase vazio". Em pouco tempo, no mesmo dia, um preso hasteia uma bandeira branca na torre central. É enfim chegado o momento de libertação dos presos.

Até a chegada dos reforços militares americanos, a guarda dos prisioneiros fica sob total responsabilidade de Hans Eiden - o prisioneiro que anunciou a tomada de Buchenwald - e de alguns soldados responsáveis pela invasão. Eiden também foi o responsável por hastear a bandeira branca no pátio central e decretar a liberdade dos prisioneiros. Rudolf, que se escondeu durante a troca de tiros, não presenciou o histórico momento da invasão americana de Buchenwald, e após certo tempo de silêncio no campo, ele decidiu sair do esconderijo prudentemente. $E$, dessa forma, "do lado de fora, volta a ser um homem livre", e o ambiente era "[...] de euforia - da libertação e dos reencontros. Enfim, eles poderão reaprender a viver. E, sobretudo, sair de Buchenwald" (SCHWAB; BRAZDA, 2012, p. 149).

Apesar do recorte deste artigo centrar-se na figura de Brazda é importante pontuar que há outros relatos de sobreviventes homossexuais do holocausto que contaram ao mundo suas histórias, como por exemplo, Josef Kohout, primeiro sobrevivente a relatar o que homens homossexuais viveram nos campos de concentração (SETTERINGTON, 2013). Inclusive, na obra de Ken Setterington, intitulada Marcados pelo Triângulo Rosa (2013), o autor retrata histórias de alemães homossexuais presos ou mortos nos campos de concentração, suas vivências, como eram mantidos em barracões separados dos outros e sofriam preconceito de outros prisioneiros. Outra autobiografia impactante Moi, Pierre Seel, déporté homosexuel ${ }^{5}$ relata a experiência de um deportado durante a Segunda Guerra Mundial e prisioneiro de campo de concentração nazista. 
São materiais, fontes históricas, que nos permitem analisar o período do holocausto nazista na segunda guerra, sob a ótica da diversidade sexual, e como estas experiências auxiliaram para o debate acerca da dignidade humana no pós-guerra e a luta pelos direitos humanos.

\title{
A Dignidade Humana e os Direitos Humanos
}

Marion Magalhães (2001), citando a teórica política Hannah Arendt (1993), analisa perspectivas relacionadas às experiências retratadas nos campos de concentração, possibilitando definir a complexidade da tortura imposta aos presos de tais localidades, determinando-as metaforicamente como um inferno terreno, no qual é possível associar:

[...] inferno, como foi concebido pela cosmovisão judaico-cristã à época medieval, não era o lugar da morte, mas do sofrimento eterno, de um sofrimento tão grande que as pessoas preferiam morrer a ter de suportá-lo. É bem verdade que semelhantes sensações devem ter tido aqueles prisioneiros (ARENDT, 1993apud MAGALHÃES, 2001, p. 64).

A postura passiva dos prisioneiros dos campos de concentração em relação ao autoritarismo e tirania dos policiais e generais da SS denuncia a atmosfera opressora que envolvia tais localidades de detenção. Hannah Arendt (1996) associa tal período a um laboratório humano, verificando que:

\begin{abstract}
Os campos são um laboratório vivo que revelam que tudo é possível, que os humanos podem criar e habitar um mundo onde as distinções entre vida e morte, verdade e falsidade, aparência e realidade, corpo e alma, e até vítima e algoz são constantemente confundidas [...], os campos apresentam, primeiro, a morte jurídica; depois a destruição moral e finalmente que a individualidade do ser tem de ser esmagada (ARENDT, 1996 apud MAGALHÃES, 2001, p. 66).
\end{abstract}

Além do controle dos prisioneiros, a prática da tortura e violência física nos campos de concentração servia de reforço ao entusiasmo nutrido pelo chefe carismático ou pela restauração da ordem, lógica presente nas origens das estruturas dos regimes autoritários. 0 historiador Pierre Ansart (1983) relacionou tais métodos de disciplina e obediência impostos pelos nazistas aos prisioneiros, possibilitando interpretar que:

[...] eles precedem sempre, segundo 0 autor, um conjunto de paixões políticas, alimentadas num pequeno grupo (geralmente, de caráter sectário), que são expressas de forma a denunciar, com intensa violência verbal (ou mesmo violência física), o inimigo: os imperialistas, os judeus, o Tratado de Versalhes, a burguesia, os criminosos, os subversivos. Quando identificados como forças do mal, o ódio é iniciado sem clemência, ao mesmo tempo em que é produzida uma identificação afetiva com o chefe do grupo (ANSART, 1983, p. 132).

Ao abordar a análise do comportamento homossexual no campo de concentração de Buchenwald, sabe-se que menos de $1 \%$ dos prisioneiros ali presentes foram detidos devido às práticas sexuais condenadas pelo parágrafo/artigo 175 do Código Penal Alemão, contando que tal campo possuía a maior concentração de homossexuais de todos os campos de concentração. Ou 
seja, somavam-se cerca de 650 prisioneiros homossexuais em toda a trajetória de utilização, e os demais prisioneiros, cerca de 50 mil homens, foram detidos devido a outras infrações e perseguições instauradas após o início da gestão dos nazistas. Setterington (2013) elaborou uma tabela censitária a respeito dos homossexuais detidos em campos de concentração nazistas e em departamentos policiais locais, com prisões preventivas e/ou em primeira instância, como ilustrado:

Tabela 1 - Censo alemão em relação à prisão de homossexuais pelos nazistas

\begin{tabular}{|c|c|}
\hline Ano & Número de presos homossexuais \\
\hline 1933 & 853 \\
\hline 1934 & 948 \\
\hline 1935 & 2.106 \\
\hline 1936 & 5.320 \\
\hline 1937 & 8.271 \\
\hline 1938 & 8.562 \\
\hline 1939 & 7.614 \\
\hline 1940 & 3.773 \\
\hline 1941 & 3.735 \\
\hline 1942 & 3.963 \\
\hline
\end{tabular}

Fonte: Setterington (2017, p. 49).

Observando tais dados, pode-se afirmar que os prisioneiros não homossexuais representavam uma parcela superior ao número de detentos gays, porém, o relacionamento homossexual nos campos de concentração, assim como nas prisões alemãs, era uma prática comum. No campo da Psicologia, como contribui a pesquisadora, psicóloga e educadora sexual Mary Figueiró (2007), a orientação sexual pode aflorar-se em diferentes aspectos, e nesse sentido pode ser interpretada a partir de duas vertentes. Cabe refletir que:

Quando a orientação homossexual está arraigada na pessoa e em seu psiquismo, falamos em homossexualidade primária, ou de profundidade. Neste caso, o apaixonar-se vai se dar apenas pela pessoa do mesmo sexo, influenciando, fortemente, os rumos das experiências de vida da pessoa. Há, ainda, a homossexualidade secundária, ou também denominada de circunstancial, ou "de superfície", na qual a atração homossexual se dá de maneira não tão rigorosa e está associada às circunstâncias, muitas vezes, passageiras. Pode se dar como consequência de carências devido à falta de parceiros do sexo oposto, como é caso de pessoas que vivem muito tempo em prisões, quartéis, conventos ou seminários. Pode se dar, também, devido à inibição e ao acanhamento ao relacionar-se com o sexo oposto (MÜLLER apud FIGUEIRÓ, 2007, p. 33). 
Quando não praticados por indivíduos nessas circunstâncias, a homossexualidade era utilizada como ferramenta de favores dos Kapos - prisioneiros que possuíam certas relações de poder na hierarquia nazista -, fazendo com que alguns dos prisioneiros prestassem favores sexuais a estes homens em troca de mais alimentos, envolvimento em decisões do alojamento em que viviam, em trocas de favores, como a própria preservação de suas vidas. Com o ápice da Segunda Guerra Mundial em 1943, a população dos campos aumentou bruscamente em quantidade e em idade, e os nazistas necessitavam de mais espaço para abrigar os prisioneiros europeus de várias origens, entre eles russos, poloneses e judeus, que chegaram após a captura e anexação de regiões ao Reich. E os detentos lutavam pela sobrevivência em meio às circunstâncias em que se encontravam, submetendo-se aos abusos. Isso também foi retratado por Rudolf Brazda, afirmando em sua posterior biografia que "prestar os favores sexuais exigidos pelo mais velho não agradava à sua sexualidade, mas era um mal necessário" (SCHWAB; BRAZDA, 2012, p. 135).

O método de interferência do Estado alemão em relação a circunstâncias de cunho particular de seus cidadãos, como retratado no caso da perda dos direitos civis de Rudolf Brazda por este ser homossexual e ter relações homoafetivas com seu companheiro, Werner, nos faz refletir sobre a constante importância da equidade entre os seres humanos, ou seja, incentivar políticas públicas adequadas para as necessidades de diferentes grupos sociais, proporcionando a igualdade entre tais grupos, considerando a concepção de dignidade.

A dignidade humana tem como princípio valorizar a permanência e a existência do ser humano na sociedade. Trata-se de um tema discutido e explorado de diversas formas, com contribuições científicas, filosóficas e religiosas, que buscam engendrar e influenciar nos diversos setores da sociedade, por meio de seus simpatizantes, historiadores e estudiosos.

Analisando do campo filosófico, o processo moderno de construção das escolas de filosofia tornou-se imprescindível para a atribuição de fundamentos intelectuais de liberdade, tomando como princípio a existência da razão e a liberdade do ser humano, isento de diferenças de gênero, raça, sexo, religião e, consequentemente, fomentando a criação da base de direitos inerentes e abrangentes aos cidadãos (COMPARATO, 2010, p. 24). Na Grécia Antiga, faz-se necessário citar que a presença de obras e peças teatrais referentes ao tema da criação e justificativa da dignidade eram recorrentes. 0 dramaturgo grego Ésquilo, em sua obra Prometeu Acorrentado, adquire o papel social de criador da raça humana, caracterização na qual relata que foi possível tornar os homens "seres de razão, capazes de pensar", ensinados a desenvolver: 
A árdua ciência da nascente e do poente dos astros. Depois, foi a vez da ciência dos números, a primeira de todas, que inventei para eles, assim como a das letras combinadas, memória de todas as coisas, labor que engendra as artes (ÉSQUILO, 2005, p. 11).

Desde os tempos mais remotos de nossa civilização, os campos de influência sobre as sociedades preocupavam-se em justificar a preservação e existência dos seres humanos e, assim, incentivar a criação de políticas públicas e organizacionais que visassem garantir direitos e deveres a estes. Entretanto, o período em que os nazistas estiveram no poder destacou-se como um dos mais distantes da concepção de valorização dos indivíduos, consequentemente propiciando situaçõeslimite, das quais suas vítimas se recordam dolorosamente, além das diversas consequências para a população alemã minoritária, sendo esta tratada de forma marginalizada, considerando os homossexuais, judeus, ciganos, testemunhas de Jeová, doentes físicos e mentais e da clara perseguição política instaurada pelos nazistas em relação aos partidários de esquerda e aos comunistas. Em relação a isso, o governo de Hitler possuía deliberada autonomia perante julgamentos, experimentos e outros eventos vivenciados em campos de concentração e nos cenários da guerra.

As experiências com a prisão arbitrária e severa de homossexuais masculinos na Alemanha nazista reacenderam o debate diplomático internacional em relação aos direitos humanos e às proteções individuais. Mas cabe salientar que no pós-guerra e na abertura dos campos de concentração, os homossexuais ainda eram estigmatizados pela sociedade, o que impossibilitou:

[...] dessas pessoas prestarem seu depoimento, escreverem suas memórias, e contarem, enfim, o que haviam passado, inclusive pelo fato de ainda existirem leis anti-homossexuais em vigor. No caso da França, uma lei que havia sido promulgada em 1942, pelo governo Vichy, reinscrevia no Código Napoleônico, entre os "delitos" sexuais, as relações entre pessoas do mesmo sexo como uma incriminação agravante. Isso depois de um século e meio de tolerância social, pois, na França, não havia algo na lei como o Parágrafo 175 alemão (ELIDIO, 2010, p. 1).

Ou seja, mesmo com os debates acerca dos direitos humanos florescendo na Europa, os homossexuais ainda viviam na sua invisibilidade e clandestinidade. O Parágrafo 175 , do código alemão, continuou em vigor no lado oriental até 1967, e, no lado ocidental, até 1969.

Os testemunhos mostram que, em certos casos pelo menos, as forças de ocupação aliadas enviaram os deportados homossexuais ao sistema penitenciário tradicional, considerandoos como delinquentes sexuais que haviam merecido seu castigo por parte dos nazistas e que continuavam a merecê-lo após a Libertação (KOSKOVICH apud LE BITOUX, 2002, p. 151).

Ser homossexual no pós-guerra continuou sendo um período de horror, de perseguições e prisões pelo Europa. Neste caso, quando se inicia então os movimentos em torno dos direitos humanos, torna-se um viés de discussão e possíveis garantias em existir e ter contemplado seus direitos fundamentais. 
A história dos direitos humanos une-se ao debate em torno da dignidade humana característica de ter ciência do valor próprio e dos demais enquanto indivíduos - , ou seja, incorpora todos os ganhos e interpretações de diferentes culturas, como a grega e a romana, e as interpreta através de marcos legais que garantem o essencial da liberdade e preservação dos indivíduos.

A pós o desligamento da Liga das Nações em outubro de 1945, a responsabilidade diplomática por garantir os direitos humanos foi repassada para a recém-criada Organização das Nações Unidas (ONU), sediada em Paris até então, que além de buscar o debate da garantia de direitos entre os países, reforçou o Pacto da Liga das Nações - o principal documento em relação aos direitos humanos, embora este tratasse de forma tênue do assunto, destacando-se na definição das sanções aos países perdedores em relação ao armistício da Primeira Guerra - e criou a Declaração Universal dos Direitos Humanos, em 1946.

Nesse sentido, tem-se a necessidade de criação de documentos jurídicos ou declarações que visem garantir e/ou influenciar na concepção dos direitos ao homem, de forma que valorizem a permanência e a proteção destes na sociedade. É certo que a Declaração Universal dos Direitos Humanos, assim como o Pacto da Liga das Nações, possuía artigos importantíssimos para a concepção dos direitos humanos. Este último, com o artigo 23, propunha aos Estados signatários a responsabilidade diplomática por garantir condições de trabalho e equânimes para homens e mulheres; garantir acompanhamento à população indígena residente no país; corrigir os crimes de tráfico de mulheres e crianças; combater o tráfico de drogas; e garantir o livre-comércio internamente e entre países.

A ONU, com atual sede em Nova York, foi criada em junho de 1945, pouco tempo após o fim da Segunda Guerra Mundial. Nesse período, com forte desgaste diplomático propiciado pela rivalidade bélica, instaurou-se a necessidade de recriar uma organização diplomática para atribuir direitos e deveres a serem assegurados e respeitados pelos países que se submetessem à nova organização.

Atualmente 193 Estados participam da ONU e são signatários da Declaração Universal dos Direitos Humanos (DUDH). Nesta, considera-se que "o reconhecimento da dignidade inerente a todos os membros da família humana e dos seus direitos iguais e inalienáveis" constitui o fundamento da liberdade entre os indivíduos, definido no preâmbulo da DUDH, e que sua ausência se torna responsável por conduzir "a atos de barbárie que revoltam a consciência da Humanidade" (ONU, 1998, p. 2). Tal código de conduta instaurou-se após a desastrosa experiência bélica da Segunda Guerra, buscando ressignificar a dignidade e a importância humana, conduzindo os indivíduos a agirem de forma cívica e cidadã. 
A sessão de votação da Declaração Universal dos Direitos Humanos, submissa à resolução 217-A da Assembleia Geral das Nações Unidas, ocorreu em 10 de dezembro de 1948, presidida pela até então primeira-dama estadunidense Eleanor Roosevelt, em Paris. Os países participantes da sessão consideravam que "o advento de um mundo em que todos gozem de liberdade de palavra, de crença e de liberdade de palavra, de crença e da liberdade de viverem a salvo do temor e da necessidade foi proclamado como a mais alta aspiração do ser humano" (ONU, 1998, p. 2), dessa forma abrindo precedentes para a democracia, a liberdade de expressão e o reconhecimento da dignidade de seus indivíduos.

Os trinta artigos propostos pela Declaração buscavam assegurar o direito à liberdade, à segurança, à vida, e tais garantias independem de "qualquer espécie, seja de raça, cor, sexo, idioma, religião, opinião pública ou de outra natureza, origem nacional ou social, riqueza, nascimento, ou qualquer outra condição" (ONU, 1998, p. 5). Este princípio de equidade entre os constituintes da sociedade foi determinante para a garantia dos direitos fundamentais e, nesse sentido, também possibilitou atribuir direitos à população LGBTTI.

Outra análise proveniente da importância dos direitos humanos se dá pela perspectiva de embasamento do direito. Após o século XVIII, com as Revoluções Americana e Francesa ocorre uma inovação no modo de pensar a política. Celso Lafer (1995) justifica que "até então a preocupação predominante dos pensadores políticos era com o bom governo", e posteriormente inaugura-se a época da perspectiva dos governados, dessa forma substituindo a "[...] ênfase na noção de dever dos súditos pela da promoção da noção de direitos do cidadão. Daí, nas palavras de Hannah Arendt, a ideia de o direito ter direitos, que estará na base da construção dos regimes democráticos da Idade Contemporânea" (LAFER, 1995, p. 171). Isso implica diretamente no conceito de direito novo, tratando de forma axiológica o ser humano como fim e não meio, sendo que este deve possuir "direito a um lugar no mundo; um mundo que encontra um terreno comum entre a Ética e a Política através da associação convergentes de três grandes temas: direitos humanos e democracia no plano interno e paz no plano internacional" (LAFER, 1995, p. 172).

\section{Considerações Finais}

A herança dos conceitos advindos dos estudos eugênicos foi determinante para a apropriação do nazismo proposto por Hitler. Instaurou-se um ambiente de medo, em que o diferente era combatido, e dessa forma a população LGBTTI passou a sofrer os efeitos do novo governante alemão. 0 autoritarismo foi uma das marcas do nazismo, que se preocupou em reforçar o código constitucional vigente no país com relação à reprodução da população, que deveria atender aos 
preceitos maritais impostos em 1935, realizando casamentos apenas entre arianos ou não arianos heterossexuais - e os partidários de esquerda, também considerados como comunistas, que, segundo a perspectiva nazista, poderiam ameaçar a continuidade do regime.

Estima-se que cerca de 45 mil homossexuais foram presos devido ao artigo 175 do Código Penal Alemão, que criminalizava diretamente o contato físico-sexual entre homossexuais masculinos ou entre homens e diferentes espécies, caracterizando a zoofilia. Desse número, a avassaladora maioria seguiu para outras regiões fora do território alemão, transformaram-se em desertores da pátria - também tratados como personas non gratas - e tiveram de deixar amigos, familiares e estruturas mínimas de sobrevivência. Uma outra minoria - incluindo o biografado Rudolf Brazda -, acabou sendo presa reincidentemente e assinalando sua tortura ao ser transferida para os campos de concentração, como no caso de Brazda em Buchenwald.

Uma das medidas punitivas dos nazistas, como a teoria da reversão da polaridade sexual, proposta por Vaernet, levou cerca de $55 \%$ dos prisioneiros homossexuais de Buchenwald à morte, devido ao posicionamento homofóbico dos nazistas, que enxergavam os homossexuais a partir da perspectiva da heteronormatividade e da interpretação médica como desvio mental. Além disso, Rudolf foi testemunha na série de dizimações dos militares das tropas contrárias na guerra, que ao serem capturadas eram trazidas aos campos de concentração e fuziladas uma a uma. 0 tratamento também era administrado aos prisioneiros indisciplinados, que acabavam sendo mortos no próprio campo de concentração onde cumpriam suas penas, em vez de serem encaminhados aos campos de extermínio, como no caso dos judeus.

É certo que tais eventos e experiências aterrorizantes vivenciadas durante a gestão de Hitler, assim como as vivências dos prisioneiros dos campos de concentração, foram não só importantes como também essenciais para a discussão e a implementação de direitos igualitários natos ao homem. O campo dos direitos humanos surgiu como uma resposta a todo antissemitismo, homofobia, racismo e intolerância disseminados pelos discursos ultranacionalistas de Adolf Hitler. Atender à população marginalizada e propensa à violência é uma das marcas da Declaração Universal dos Direitos Humanos, que ganhou outras interpretações jurídicas, como no Brasil, em que as políticas públicas da ONU são tratadas como a base do direito novo, onde as ciências jurídicas nacionais e internacionais distanciam-se das esferas externas ao homem e passam a analisar perspectivas natas a toda e qualquer pessoa, garantindo direitos fundamentais de liberdade, segurança e proteção individual. 


\section{Referências}

ANSART, Pierre. La gestion des passions politiques. Lausanne: L'Age d'Homme, 1983.

AVELAR, Alexandre de Sá. A biografia como escrita da História: possibilidades, limites e tensões. Revista Dimensões, Vitória, v. 24, n. 1, p. 157-172, fev./mar. 2010.

BOURDIEU, Pierre Félix. A ilusão biográfica: usos e abusos da história oral. São Paulo: FGV, 1996.

CAETANO, Tiago Lemanczuk Fraga. Mein Kampf e o Ideário Nazista. Revista Eletrônica de Direito, Brasília, v. 1, n. 4, maio/ago. 2010.

COMPARATO, Fábio Konder. A afirmação histórica dos direitos humanos. São Paulo: Saraiva, 2010.

ÉSQUILO. Prometeu acorrentado. São Paulo: Clássicos J ackson, 2005.

FIGUEIRÓ, Mary Neide Damico (org.). Homossexualidade e Educação Sexual: construindo respeito à diversidade. Londrina: EDUEL, 2007.

GUERRA, Andréa. Do Holocausto nazista à nova eugenia do século XXI. Revista Tendências, Crato, v. 12, n. 1, p. 4-5, jun. 2014.

LAFER, Celso. A ONU e os direitos humanos. Estudos Avançados, São Paulo, v. 9, n. 25, p. 169-185, jan./jun. 1995.

LONGERICH, Peter. A arquitetura da solução final. Revista BBC História, São Paulo, v. 1, n. 1, p. 1623, fev./jun. 2008.

MAGALHÃES, Marion Brepohl de. Campo de concentração: experiência limite. Revista História:

Questões e Debates, Curitiba, v. 1, n. 35, p. 61-79, jan./jun. 2001.

MOLINA, Luana Pagano Peres. Professores homossexuais: suas vivências frente à Comunidade Escolar. 2010. 90 f. Monografia (Especialização em Psicologia Aplicada à Educação) - Universidade Estadual de Londrina, Londrina, 2010.

ONU - ORGANIZAÇÃO DAS NAÇÕES UNIDAS PARA A EDUCAÇÃO, A CIÊNCIA E A CULTURA. Declaração Universal dos Direitos Humanos. Brasília: ONU, 1998.

SCHWAB, Jean-Luc; BRAZDA; Rudolf. Triângulo rosa: um homossexual no campo de concentração nazista. São Paulo: Mescla, 2012.

SEEL, Pierre; LE BITOUX, Jean. Moi, Pierre Seel, déporté homosexuel. Paris: Éditions Calmann-Lévy, 1994.

SETTERINGTON, Ken. Marcados pelo triângulo rosa. São Paulo: Melhoramentos, 2013.

Recebido em 05/06/2018

Aprovado em 21/11/2018 